\author{
Pentingnya Lingkungan \\ dalam Pembelajaran Bahasa Indonesia \\ Aulia Rahma Putri/19016078 \\ auliarahmaputri2000@gmail.com
}

Dewasa ini permasalahan dari waktu ke waktu terus mengalami pertambahan, hal tersebut disebabkan oleh banyaknya peristiwa-peristiwa yang terjadi, baik yang disebabkan oleh kesalahan manusia maupun gejala alam. Kesalahan yang dilakukan oleh manusia, seperti membuang limbah ke sungai, menebang kayu sembarangan, dan banyak hal lainnya yang dapat merusak ekosistem lingkungan. Tung dan Wihardjo (dalam Ramadhan et al, 2019), masalah yang terjadi di lingkungan disebabkan oleh aktivitas manusia yang ceroboh dan intensif didaerah tempat ia tinggal, hal ini dilakukan untuk meningkatkan kualitas hidupnya masing-masing. Banyak dari manusia tidak memikirkan lingkungan ketika melakukan hal-hal yang dapat merusak lingkungan.

Lingkungan sangatlah penting bagi kelancaran proses penting bagi proses pembelajaran. Salah satu siasat yang dapat dilakukan untuk memperkecil kerusakan lingkungan adalah dengan menanamkan rasa peduli terhadap lingkungan kepada generasi yang akan datang adalah dengan menanamkan sikap peduli terhadap lingkungan sedari dini kepada generasi penerus bangsa. Nkwetisma (dalam Ramadhan et al, 2019), pendidikan lingkungan merupakan suatu usaha yang dilakukan secara sadar untuk mengajar dan menarik perhatian manusia tentang bagaimana fungsi lingkungan alam dan bagaimana manusia ini dapat mengelola dan melindunginya. Ramadhan et al (2019) menyatakan pendidikan lingkungan mampu membantu siswa memikirkan kembali hubungan atau korelasi antara manusia dengan lingkungannya.

Sukma (2020) mengatakan sebagai individu, manusia memiliki tanggung jawab untuk memecahkan masalah lingkungan. Satu solusi yang dapat dilakukan untuk mengatasi permasalahan lingkungan adalah dengan pengetahuan yang benar dari semua faktor lingkungan untuk menjaga lingkungan. Upaya paling efektif untuk mencapai ini tujuannya adalah sistem pendidikan lingkungan yang memadai, dipetakan dan ditujukan untuk memberikan kesadaran, hati nurani dan informasi tentang masalah lingkungan kepada siswa dari semua tingkatan. Ditingkatkan kesadaran tentang lingkungan dapat diperoleh melalui 
proses pendidikan. Pendidikan adalah kuncinya elemen dalam pencegahan dan penyelesaian masalah lingkungan.

Zulhafizh et al (2013) mengungkapkan sikap dan motivasi belajar yang tinggi pada siswa diharapkan dapat membantu dalam pencapaian hasil belajar yang maksimal. Elfia Sukma et al (2017) menyatakan bahwa pembelajaran literasi di kelas awal membutuhkan alat atau bahan yang dapat membantu siswa dalam mengoptimalkan kemampuan membaca dan menulis. Karakteristik siswa kelas awal yang memiliki rentang konsentrasi yang lebih pendek membutuhkan dukungan sehingga mereka tertarik dengan apa yang mereka pelajari. Media literasi seperti gambar, grafik/diagram atau objek yang menarik dapat membantu mengoptimalkan proses siswa belajar membaca dan menulis. Putri dan Syahrul (2019) mengungkapkan bahwa dalam pembelajaran di lingkungan sekolah, pengajaran membaca harus memperoleh perhatian yang serius dari pendidik di Indonesia. Melalui pengajaran, pendidik mampu mengarahkan peserta didik dalam pembelajaran bahasa. Munandar (dalam Piliang et al, 2014) menyatakan bahwa suatu kreativitas merupakan wujud dari interaksi individu dengan lingkungannya.

Arief (dalam Ramadhan et al, 2018) menyatakan bahasa memegang peranan penting dalam kehidupan manusia. Bahasa dapat mengembangkan kecerdasan intelektual, emosional, dan kecerdasan spiritual. Kemampuan bahasa siswa di Indonesia perlu ditingkatkan, terutama untuk menulis keterampilan. Keterampilan menulis merupakan keterampilan berbahasa yang paling sulit, namun perannya dalam kehidupan manusia sangat penting.

Tarigan (dalam Sukma et al 1, 2019) mengemukakan bahwa siswa dan mahasiswa yang mengikuti pendidikan, baik dalam SD, SMP, dan SMA maupun perguruan tinggi harus bisa mendengarkan bila ingin maju dalam pendidikan. Sementara, Elfia Sukma dan Vivi Putri Azrianti (2020) mengatakan Pembelajaran di sekolah yang dapat menanamkan karakter positif dalam siswa tidak bisa dipaksakan jika hanya terfokus pada pemberian materi yang berkaitan dengan karakter positif. Pada usia dini ini, cara belajar yang baik adalah belajar sambil bermain. Para guru upaya untuk memberikan materi pembelajaran dengan cara yang menarik tetapi tetap membuat siswa fokus, sehingga tujuan pembelajaran dapat tercapai. Tentang penanaman karakter positif yang dapat diintegrasikan ke dalam cerita rakyat, dapat menarik minat siswa perhatian, dengan cara belajar sambil bermain melalui aplikasi.

Berdasarkan angket yang penulis sebarkan "Pentingnya Lingkungan dalam Pembelajaran Bahasa Indonesia” kepada mahasiswa Universitas Negeri Padang semester 5, 
mahasiswa UPI YPTK Padang semester 3, Universitas Bung Hatta, mahasiswa Dharma Andalas semester 1. Dari jumlah keseluruhan 32 responden yang ikut serta dalam pengisian angket tersebut dengan persentase laki-laki $12,9 \%$ dan perempuan $87,1 \%$. Hasil laporan dari data angket melalui google form akan dijabarkan sebagai berikut.

Pernyataan pertama "Pada saat ini permasalahan lingkungan dari masa-kemasa terus bertambah, hal itu disebabkan oleh banyaknya peristiwa-peristiwa yang terjadi, baik dari kesalahan manusia itu sendiri maupun dari gejala alam" 32,3\% menyatakan sangat setuju, $71 \%$ setuju, 3,2\% tidak setuju, dan 0\% menyatakan sangat tidak setuju. Pernyataan kedua "Kesalahan manusia seperti membuang sampah ke sungai yang menyebabkan air tercemar, menebang kayu secara liar yang menyebabkan banjir dan tanah longsor, dan masih banyak lagi kerusakan-kerusakan yang disebabkan oleh tangan manusia. Kerusakan tersebut berdampak buruk bagi kelangsungan makhluk hidup" 48,4\% menyatakan sangat setuju, 51, $6 \%$ menyatakan setuju, $0 \%$ menyatakan tidak setuju, dan $0 \%$ menyatakan sangat tidak setuju. Pernyataan ketiga "Lingkungan sangat penting bagi kelancaran proses pembelajaran" 48,4\% menyatakan setuju, $0 \%$ menyatakan tidak setuju, dan $0 \%$ menyatakan sangat tidak setuju. Pernyataan keempat "Lingkungan sangat penting bagi kelancaran proses pembelajaran" $37,5 \%$ menyatakan sangat setuju, 65,6\% menyatakan setuju, $0 \%$ menyatakan tidak setuju, dan $0 \%$ menyatakan sangat tidak setuju. Pernyataan kelima "Menanamkan rasa tanggung jawab dan sadar akan lingkungan bisa dilakukan di sekolah dengan menerapkan materi lingkungan dalam pembelajaran bahasa Indonesia" 28,1\% menyatakan sangat setuju, $68.8 \%$ menyatakan setuju, $0 \%$ menyatakan tidak setuju, dan $0 \%$ menyatakan sangat tidak setuju. Pernyataan keenam "Pembelajaran berbasis lingkungan bertujuan agar siswa ikut berpartisipasi dalam menjaga dan melestarikan lingkungan" 37,5\% menyatakan sangat setuju, 65,6\% menyatakan setuju, $0 \%$ menyatakan tidak setuju, dan $0 \%$ menyatakan sangat tidak setuju. Pernyataan ketujuh "Pembelajaran mengenai lingkungan memudahkan siswa dalam memahami materi bahasa Indonesia dengan baik, menambah wawasan siswa, serta dapat membangun kecerdasan ekologis siswa" 34,4\% menyatakan sangat setuju, 62,5\% menyatakan setuju, 3,1\% menyatakan tidak setuju, dan $0 \%$ menyatakan sangat tidak setuju. Pernyataan kedelapan "Mengembangkan pengetahuan siswa tentang lingkungan sangat penting, karena dapat membantu siswa memikirkan kembali hubungan manusia dan lingkungan, memahami lingkungan, menyadari masalah lingkungan, dan mempertimbangkan masalah lingkungan yang berkaitan dengan kehidupan" 34,4\% menyatakan sangat setuju, $62,5 \%$ menyatakan setuju, 3,1\% menyatakan tidak setuju, dan $0 \%$ 
menyatakan sangat tidak setuju. Pernyataan kesembilan "Dengan mengintegrasikan pendidikan lingkungan ke dalam kelas, dapat meningkatkan minat siswa terhadap permasalahan kontemporer yang mungkin langsung mempengaruhi masa depan mereka" $31,3 \%$ menyatakan sangat setuju, 65,6\% menyatakan setuju, 3,1\% menyatakan tidak setuju, dan $0 \%$ menyatakan sangat tidak setuju. Pernyataan kesepuluh "Materi mengenai lingkungan merupakan materi yang sangat erat kaitannya dengan kehidupan sehari-hari” $37,5 \%$ menyatakan sangat setuju, 62,5\% menyatakan setuju, $0 \%$ menyatakan tidak setuju, dan $0 \%$ menyatakan sangat tidak setuju.

Dari hasil penyebaran angket kepada responden, dapat penulis simpulkan bahwa bahwa lingkungan memiliki peranan penting dalam proses pembelajaran bahasa Indonesia. Dalam pembelajaran bahasa Indonesia, pendidik seharusnya memberikan menyajikan pembelajaran dengan cara yang tepat dan menimbulkan minat belajar siswa, agar siswa dapat berkonsentrasi penuh dalam pembelajaran. 


\section{Daftra Pustaka}

Putri, Diana dan Syahrul R. (2019). Korelasi Keterampilan Membaca Pemahaman dan Keterampilan Menulis Teks Laporan Hasil Observasi Siswa Kelas VII SMP Negeri 4 Pariaman. Jurnal Pendidikan Bahasa dan Sastra Indonesia, 8(1), seri A 62-69.

Ramadhan, S., Yasnur Asri, dan Vivi Indriyani . (2018). Learning Module Design Writing Argumentative Text Based Problem-Based Learning. Advances in Social Science, Education and Humanities Research, Vol 263: 194-200.

Ramadhan, S., Elfia Sukma, dan Vivi Indriyani. (2019). Environmental Education and Disaster Mitigation Through Language Learning. IOP Conference Series: Earth and Environmental Science, 314, p. 1-9.

Ramadhan, S., Elfia Sukma, dan Vivi Indriyani. (2019). Persepsi Guru terhadap Penggunaan Bahan Ajar Bahasa Indonesia dengan Perangkat Seluler dan Aplikasi Edmodo. Seminar Internasional Riksa Bahasa.

Sukma, Elfia. (2012). Pembelajaran Sastra yang Integratif Berbasis Kompetensi. International Conference on Languages and Arts, Halaman 432-436.

Sukma E, dan VP Azrianti. (2020). Instilling Positive Characters in Students Using Folker in the Macromedia Application. Advances in Social Science, Education and Humanities Research, Volume 485.

Zulhafizh, Atmazaki, dan Syahrul Ramadhan. (2013). Kontribusi Sikap dan Motivasi Belajar Siswa terhadap Hasil Belajar Bahasa Indonesia. Jurnal Bahasa, Sastra dan Pembelajaran, Volume 1, Nomor 2, Halaman 13-28.

Sukma E, Ritawati M, dan Rizky A. (2017). Literacy Media Development in Improving Reading and Writing Skill of Early Class Students in Elementary School Padang Utara Padang. Advances in Social Science, Education and Humanities Research, Vol 118.

Sukma E. et.al. (2019). Problems in Oral Language Teaching in Primary School. Advances in Social Science. Education and Humanities Research, Volume 301. 
Piliang, Wilda S. H., Atmazaki, dan Syahrul Ramadhan. (2014). Kontribusi Kemampuan Apresiasi Sastra dan Berpikir Kreatif terhadap Keterampilan Bermain Drama pada Siswa Kelas XII IPS SMA Negeri 2 Rengat Kabupaten Indragiri Hulu. Jurnal Bahasa, Sastra dan Pembelajaran, 2(2), 75-87. 